Article

\title{
The Right to 'Have a Say' in the Deinstitutionalisation of Mental Health in Slovenia
}

\author{
Mojca Urek \\ Faculty of Social Work, University of Ljubljana, Slovenia; E-Mail: mojca.urek@fsd.uni-lj.si
}

Submitted: 30 March 2021 | Accepted: 21 June 2021| Published: 26 August 2021

\begin{abstract}
In a time when the deinstitutionalisation of mental health services has become a global and European platform and one of the main forms of care provision, a theme such as the transition of care from large institutions down to a more personal community level care might seem outlived, but the fact is that in some European countries the discussion has revolved for almost 35 years around the most basic question concerning the closure of large, asylum-type mental health institutions. In this article, I provide a historical overview and analysis of deinstitutionalisation processes in the field of mental health in Slovenia from mid-1980s onwards, interpreted in terms of achievements and gaps in community-based care and in user participation in these processes. It demonstrates some of the innovative participatory practices and their potential to transform services. A thematic data analysis was used to analyse the data collected from various primary (a focus group) and secondary sources (autobiographies, newspaper articles, round table reports, blogs) that all bear witness to the different periods of deinstitutionalisation and the user perspective in it.
\end{abstract}

\section{Keywords}

community mental health; history of deinstitutionalisation; tokenism; social movements; user participation

\section{Issue}

This article is part of the issue "Home- and Community-Based Work at the Margins of Welfare: Balancing between Disciplinary, Participatory and Caring Approaches" edited by Kirsi Juhila (Tampere University, Finland), Cecilia Hansen Löfstrand (University of Gothenburg, Sweden) and Johanna Ranta (Tampere University, Finland).

(C) 2021 by the author; licensee Cogitatio (Lisbon, Portugal). This article is licensed under a Creative Commons Attribution 4.0 International License (CC BY).

\section{Introduction}

In this article, a historical overview and analysis of deinstitutionalisation processes in the field of mental health in Slovenia will be presented, interpreted in terms of achievements and gaps in community-based care, all from the perspective of user participation in these processes. In the first part of the article, basic concepts and briefly presented contexts of both the European and Slovenian situations in this field are introduced. The findings are presented in the narrative form of the interrelated histories of deinstitutionalisation and embeddedness of the user perspective in its implementation. The conclusion summarises the main historical lessons learned so far in relation to the questions posed in this study.

\subsection{Deinstitutionalisation in Mental Health in Europe and Its Echo in Slovenia}

Perhaps the most important shift in mental health care since World War II has been the transition of care for people with long-term mental health problems from large-format mental health institutions to community providers. Deinstitutionalisation in the field of mental health usually means the closure of large, closed institutions and, subsequently the provision of community services. However, it is important to understand deinstitutionalisation in a broader context. Deinstitutionalisation is also about people gaining sovereignty in everyday life, reclaiming control over their own lives, gaining support for decision-making, and producing new ways of care that transcend the institutional patterns (Flaker, 2015; Flaker \& Ramon, 2016; Ramon, 1985). By the end of 
the 20th century, deinstitutionalisation became a universal policy of international agencies like World Health Organisation (2005), and the right to live in the community, along with others, is an important part of the United Nations Convention on the Rights of Persons with Disabilities (United Nations, 2006). It is being implemented all over the world, in some countries more and in some less successfully. The first important deinstitutionalisation process in mental health care in Europe took place in the 1970s in Italy and was pioneered by Franco Basaglia in Gorizia and Trieste. His effort resulted in Law 180, passed in 1978, that abolished the psychiatric hospitals in Italy. Early and thorough deinstitutionalisation was carried out in the Scandinavian countries, and a little later in the United Kingdom (Flaker, 2015; Ramon, 1985). Today, reforms in mental heath care have taken place in most Western European countries. In recent years, a more pronounced European platform and policy (European Expert Group on the Transition from Institutional to Community-Based Care, 2012) has been the driver to finally start the process of transition to the community in many Central and Eastern European (CEE) countries or has started anew in some of them, as is true in Slovenia.

Despite this, there are still many people interned in institutions. Even in the countries where policies have been successfully implemented there are closed units, segregation, coercion, and above all institutional practices surviving in the community, such as grouping apartments into residential compounds and targeted exclusively for people with disabilities. There are also small institutions being introduced as community-based responses (re-institutionalisation), or people from one kind of institution find themselves in another institution after closure (trans-institutionalisation; see Flaker, 2015; Flaker \& Ramon, 2016; Turnpenny et al., 2018; Zaviršek, 2017). On the other hand, community living arrangements pose challenges, such as living alone or in small groups, or they may also perpetuate isolation and segregation-which are the hallmarks of institutional life. The 'care map' in some states may now include group homes, day centres, employment support projects, advocacy, user organisations, relatives' groups, family respite, outreach crisis services, mobile teams, housing floating support, and many other forms that grow in the empty space of needs for different types of support in the community.

The development of community-based care and the efforts towards deinstitutionalisation in mental health in Slovenia differ from other countries in the CEE region where deinstitutionalisation processes have only recently begun. In Slovenia, these processes were strongly influenced by the unique 'deinstitutionalisation movement' that emerged as part of the civil society movements in the second half of the 1980s in what was then still a common socialist state of Yugoslavia and continues to this day. However, although Slovenia had a long history of deinstitutionalisation and was a pioneer of community-based mental health (including user-led) innovation in the former Yugoslavia, it still has a predominantly institutional care system. The many attempts at deinstitutionalisation, fostered firstly by the movement (which grew and expanded over the years with various disability advocacy groups, academics, users, and family members), and later other actors (the NGO sector, public sector, government bodies) created a wealth of knowledge and the technology of deinstitutionalisation along with the methods of establishing community-based care that was not followed by system-wide deinstitutionalisation reform. Although today more service users use community care than institutional care, there is still a high institutionalisation rate. For people who need more intensive support and care, it is virtually impossible to provide it in the community. In such a still double-tiered system, often ex-residents return to institutions, which has the effect of strengthening the belief in public that institutions are inevitable. But independent living is a challenge, especially in terms of affordable housing and the means to live with dignity, even for people with less intensive support needs. Slovenia still allocates the bulk of funds to finance long-term care services in an institutional setting, while the community care services remain underfunded (Flaker et al., 2015; Rafaelič et al., 2017). It seems that the new wave of deinstitutionalisation that has now come as a guideline and requirement of the European Union represents not only a new chance for real systematic reform, but also the opportunity to reflect on overlooked dimensions of the deinstitutionalisation processes in the past.

\subsection{The Transition of Care into Community and User Participation}

The ethical requirements that are a prerequisite for the process of transition to community care are at least the following: the abolition of any closure and no constraint (Mezzina et al., 2019), the abolition of guardianship and mental incapacity (Ramon et al., 2017), the introduction of the social model of mental distress (Beresford, 2005; Tew, 2011), and an empowerment (strengths) perspective and user participation (Flaker et al., 2007; Ryan et al., 2012).

User participation (and associated terms such as 'involvement,' 'inclusion,' 'co-production,' 'service user-led,' and 'peer-led') seems to be the trademark of contemporary international and European social and mental health policies (e.g., European Expert Group on the Transition from Institutional to Community-Based Care, 2012; World Health Organisation, 2010, 2015), and part of most national policies. The right of active and informed participation of everyone in decisions that affect their lives is explicitly recognised in the United Nations Convention on the Rights of Persons with Disabilities (United Nations, 2006).

User involvement in mental health services can be divided into three levels: individual, operational, and 
strategic. Involvement at an individual level is based on the belief that people have valuable insight into their own distress and can contribute to their own care (some examples include shared-decision making, self-help, self-management, advanced directives, and others). Involvement at an operational level in the day-to-day running of services may include participation in meetings or the training of mental health professionals. Finally, involvement at the strategic level has been increasingly informed by service user involvement in research and evaluation in governing bodies, and in the production or co-production of new services (Crepaz-Keay, 2014, pp. 105-108). Research findings in some countries have shown that service users have found it difficult to influence service providers and have a real impact on decision-making across all levels of service delivery (Omeni et al., 2014). Users who participate as peer supporters and peer advocates often experience that professional self-interest dominates the discourse and decision-making within the organisations (Penney \& Prescott, 2016). That's why it is inevitable that concepts such as 'inclusion' (participation, empowerment) provide tools to be given to address power practically, not just as a buzzword, a form of new talk in mental health used to pretend while actually preserving old attitudes and ways of relating (Flaker et al., 2007; Urek, 2017).

\subsection{Thesis and Research Questions}

The basic questions I present in this article are essentially three. The first is how the deinstitutionalisation movement, and in particular user-led initiatives as its vital part, have influenced deinstitutionalisation processes in mental health services in Slovenia over the last 35 years. The second is whether service users have been actively involved in the implementation of deinstitutionalisation and whether these processes have enabled them to gain more influence and contractual power, i.e., whether their autonomy and the possibility to enter into equal relationships have been increased. The last question is, is there a gap between the declarative participation policy and lived experiences of participation?

My thesis in this study is that without a simultaneous strengthening of the influence and power of users, changes in the system and services cannot really be achieved and succeed, and they only remain apparent. In the long run, they are not sustainable since they necessarily lead to the reproduction of an institutional culture and the culture of dependence. Moreover, we cannot expect user empowerment and involvement to simply come spontaneously with organisational change; this particular aspect must be provided for in deinstitutionalisation policies, concretised in action plans, taken into account in funding and continuously followed-up. In short, this is a task (and a benefit) for everyone involved in deinstitutionalisation processes, and not just a matter to be left to service user organisations to advocate for. I argue that this is a systematically neglected dimension of the deinstitutionalisation process and, to a considerable extent it is the unaccomplished part of the project of the transformation of care in Slovenia. This is why the participatory and advocatory practices (including social movements and user-led initiatives) are all the more valuable companions of this process. They are among the more dynamic, insightful, and experiencebased projects of deinstitutionalisation.

In this study, I present the interrelated and interwined histories of deinstitutionalisation on the one hand, and the embeddedness of the user perspective in the transformation of mental health services in Slovenia on the other. Several studies have been conducted on the history of deinstitutionalisation in Slovenia in recent years (Flaker, 2015; Flaker et al., 2020; Rafaelič et al., 2017; Zaviršek, 2017), but so far this aspect of history has not been highlighted, which I consider the original contribution of this study.

\section{Research Methods and Data}

The aim of this article, however, is not an in-depth study of the history that spans nearly four decades. The main interest is to highlight the main periods and milestones that are relevant in terms of key challenges and the potential of user knowledge to impact the reform processes-as reflected in the research questions-with the movement acting as a driver and amplifier of these voices. These marginalised aspects of knowledgewhich have usually been considered less important-will be integrated into the main historical narrative.

The listed main historical periods, milestones, actors leading the process and more relevant attempts to reform the system of mental health services have served as a basic matrix that also turned out relevant in terms of referencing users' projects and making sense of the role of the user perspective through time and these processes.

The criteria for placing the data of various sources in a matrix that give evidence of the development of users' voices in various periods and, the guiding principle of arranging and analysing the material were the research questions to which I kept returning. The themes that crystallised in these periods as relevant were also partly identified by means of reference literature that helped to additionally categorise and analyse various practices and place them in a social and political context. Dispersed data on various user projects and practices that had a relevant impact on their empowerment were also found in reference literature.

Various other sources that were used as secondary oral, written, and visual sources were, for instance, leaflets and photographs (of camps, actions, various events), documentary films (Markun \& Švara, 2018; Muratović, 2020; Robar Dorin, 1988), literary autobiographies (i.e., Lapuh Maležič, 2016), newspaper articles from Altra: A Newspaper for Innovation in Mental Health (issues published between 1994 and 2000), online diaries 
and blogs (i.e., a blog of the friends of deinstitutionalisation by Vito Flaker), an exhibition (Museum of Madness), and other sources that bear witness to the different periods of deinstitutionalisation and user perspectives in it and were collected over a longer period of time. Furthermore, the informal stories and anecdotes, for instance of people's endeavours to get out of an institution and stay in the community, circulating as a collective memory among the people who were actively involved in the process were also documented over a longer period of time. Round tables and public tribunes organised by the local user association should also be mentioned as a source. At least two played a more important role in this article, one was held on 2nd March 2021 (on how the epidemic of Covid-19 affected the peer-support and solidarity networks) and one on 28th June 2019 (on the users' view of deinstitutionalisation). I have taken the notes which helped me to fill in the gap of the missing pieces of knowledge pertaining to the final period of the last two years.

Last, but not least, the primary data was collected through a focus group interview with three lead members of the user association Svizci (the Marmots), which was held on 29th April 2019. It lasted three hours and was held at the Faculty of Social Work. Some of the orientation themes for discussion involved: evaluation of the current process of deinstitutionalisation, the positive and negative aspects of community care (housing, income, work), experiences in involvement; advocacy, and other practices that empower the possibility of decision-making. The selection of this association was based on the fact that it is, to my knowledge, the only user association that is keenly interested in the processes of deinstitutionalisation.

Thematic data analysis was used on the transcribed focus group interview and various documented materials, involving both a 'data-driven' and 'inductive' approaches (in the sense that the themes identified were commensurate with the literature). In some places, only a simple chronological arrangement of the documentary material was undertaken. This was combined with a biographical approach when presenting the biographical bits of histories of both users who become emblematic of the movement and the more invisible, who can be described in terms of 'hidden activists' (Rose, 2018), as well as of my own lived experiences in these processes.

I was involved in the subject researched in this study in many roles which gave the autobiographical and autoethnographic dimension to this study. This is not meant in a strictly methodological sense, but as selfreflection upon my position as a researcher, as well as in connecting personal experience to wider social meanings (Spry, 2001). My roles include being a student at the beginning of the deinstitutionalisation process, an activist in the movement, a volunteer, an academic, and a researcher. I understand my biased and involved position as an advantage which gives me knowledge and insights that might be otherwise missing. In addition, the autobiographical stance partly affected the narrative style of representation in this article.

\section{The Return of 'the Forgotten': Deinstitutionalisation in Slovenia}

The foundations of the deinstitutionalisation of the mental health field in Slovenia were set in the mid 1980s, although there are many aspects of this process which had been founded even before (deinstitutionalisation of children's and youth services in the 1970s and 1980s). Deinstitutionalisation in mental health occurred in several waves that can be summarised in the period of the last nearly four decades, with different actors playing a leading role (i.e., the social movement, NGO sector, public sector, and government bodies; see Flaker et al., 2008; Flaker et al., 2015). With the changing of eras and key developments, the position of users changed significantly, along with the role of social movement as the actor in the processes of change.

\subsection{0s-1990s: Users as Companions of the Movement for Deinstitutionalisation}

I first heard of deinstitutionalisation in the second half of the 1980s, when the students of the then School for Social Workers at the University of Ljubljana (now the Faculty of Social Work) first started to pay visits to the state asylum Institution for the Mentally and Neurologically III, Hrastovec-Trate (in 2010 it changed its name to the Social Care Home, Hrastovec-Trate; hereinafter Hrastovec). Hrastovec, with over 600 residents, was at the time one of six large asylum-type social care homes housed in two castles in a remote and isolated area in Northeastern Slovenia. The School of Social Work organised international volunteer camps where students and residents of the asylum socialised on more equal terms. At the end of the 1980s, some activists among the students and professors, along with other supporters formed the Committee for Social Protection of Madness. Various aspects of life in the Hrastovec asylum and of events and happenings in the camps are welldocumented and reflected in published diaries, reports, and papers in the publications Flaker and Urek (1988) and Urek and Zaviršek (1991), as well as in a documentary directed by Robar Dorin (1988) and in a permanent exhibition in the Museum of Madness in Trate Castle, which at that time still housed the state asylum. The group continued to organise camps, events, and public discussions. In the 1990s, it became the first mental health NGO in former Yugoslavia and started to provide community services. In 1992, it established the first group home in the whole of Eastern Europe. With the naive optimism of youth, and in the midst of the lively bubbling of a variety of other civil social movements which were opening up new social issues, it was impossible to even imagine that 35 years later we would 
still have to deal with the same issue of the closure of institutions.

The users were relevant companions of the movement and perhaps for the first time, they had a say, but the main initiative and articulation of demands came from the people who did not have direct 'user experience.' It seems that in the first place, the movement had only begun to open the space of options for later autonomous user-led initiatives. For all who have participated in the activities of the movement, opportunities have grown to form equal relationships and friendships with people from whom they were previously separated by social distance. This was a new and valuable experience for all, which strengthened the sense of 'alliance in the same goal.'

\subsection{0s-2000s: User-led Alternatives as Experiments and Innovations in the Time of the Emergence of the NGO Sector}

\subsubsection{Development of Community Services and 'NGO-isation of Resistance'}

The first community services-group homes, day centres and clubs, self-help, advocacy and user associations, carers' forums, women's crisis and counselling services, and social enterprises were introduced in the 1990s in the NGO sector which was the leading actor in the second stage of deinstitutionalisation. The major resource and the hub for these developments was the EU-funded (Tempus) international interdisciplinary postgraduate programme Community Mental Health Studies established by the leading members of the movement at the School for Social Work at University of Ljubljana. The British impact provided some solutions such as advocacy, users' run services, personal planning, direct payments, while the Italian input was in the knowledge how to organise services, and the collective way of working. These approaches were coupled with Slovenia's own tradition and knowledge, which guarantee the autonomous development of innovations (Flaker et al., 2020; Flaker \& Leskošek, 1995; Ramon, 1995).

The 1990s witnessed rapid growth of the NGO sector, the process some called the NGO-isation of civil society, which was characteristic for the whole of Eastern Europe. This process had many good and some bad effects. The good ones involved the concrete steps that were taken in the direction of the organisational innovations and in providing community services and their funding. In the 1990s, the Ministry of Social Affairs funded many new social innovations in the community through tenders for projects to which NGOs applied. What was initially a good and optimistic starting point eventually proved to be an obstacle, as 'projectification' of innovation in the long term meant instability, low wages for staff, and uncertainty for users as to whether they would be able to stay in the community service. It was not uncommon for NGO staff to prefer to maintain a group home at the expense of their salary when funding was lacking. At the same time, the political sharpness of the movements softened. The members of the movement became preoccupied with the functioning of their organisations, busy with innovations, and lost their advocacy edge (Flaker et al., 2020; Rafaelič et al., 2017).

NGOs are now dependent on state funding and they have been put in a position of competing against each other for territory and funds, which often weakens solidarity. Users became 'our' and 'your' users, the users of this or that NGO. Such a 'feudal' division was not particularly helpful in encouraging users to be more connected to each other with regard to shared issues. Throughout the 1990s, users slowly turned from the 'companions in the movement' to the 'clients and users.' Within the new professional culture, the sense of 'alliances for the same goal' was less and less reflected in the contacts between users and professionals.

\subsubsection{User-led Innovations and 'Hidden Activism'}

In contrast, this is the period of the emergence of some pioneering and daring user-led projects, which, however, mainly did not become formalised or acquired more stable funding. Among the insightful user or mixed initiatives that were emerging and disappearing, there were different forms of peer advocacy and self-help initiatives undertaken by the people with experience in mental health and committed relatives and friends (Lamovec, 2001). An important figure in this area was Tanja Lamovec, combining her academic work with her experience as a survivor, and with her innovation work in mental health. Even now, her books (Lamovec, 1995, 1998) are still the core study literature for prospective social workers. For many years, Igor Spreizer was the legendary editor of Altra: A Newspaper for Innovation in Mental Health (1994-2000) that covered the most pressing issues and emerging innovations in mental health. He was also a co-organiser of the first user conference in Slovenia, which eventually brought together users from all mental health NGOs in Slovenia. In the mid-1990s, the user association Paradoks established the first-and so far, also the last-user-led crisis centre. It worked on the principle of a cooperative for mutual help. The manual of work during the crisis that they designed is still relevant today (Lamovec \& Spreizer, 2001). Unfortunately, there is no quantitative or qualitative evidence of this pioneering experiment, which eventually died off. However, in personal communication with the users involved in this project which I have had on many occasions over the years, it was noticeable that users/volunteers of the crisis centre felt safer there than on the acute wards of the hospital and were supported efficiently for the most part. This is in line with studies comparing acute psychiatric wards and crisis residential alternatives (e.g., Sweeney et al., 2014).

These experiences and other alternatives which enable people to have more control and be less exposed 
to humiliating rituals have to a large extent remained a hidden local knowledge and part of user subcultures. This is why singular anecdotes spread by word-of-mouth and that testify about the historical perseverance and resourcefulness of people with problems in mental health, so that they can maintain their dignity and control over their lives, are so much more valuable and worthy of more systematic documentation. Such is the inspiring story about a lady in her late middle years who with the power of her will, stubbornness, and determination managed to get out from the secure and closed unit of the Hrastovec asylum, where she lived from her childhood, and finally returned to the community. For several years, she insistently wrote to and called the Slovenian Ombudsman Office, requesting to be let out from the institution, until she actually made this happen. Presently, she has lived for at least 20 years in the residential group home in Ljubljana.

Although there was no specific participation policy in mental health during this period, we are dealing with perhaps the strongest imprint of autonomous user projects on the mental health care map. They believed that people with first-person experiences had valuable insights into their own distress and could help themselves on an individual level. They participated on an operational level in running services in NGOs. Finally, they worked strategically to build alliances among users, as well as their own services based on mutual support.

When we discuss the history of deinstitutionalisation, user and movement contributions are often overlooked. As well, actors such as experts, directors, ministries, and academics are highlighted, along with the indicators, such as the number of people resettled, the number of new group homes, and so on, while people who influenced this development in numerous ways, from grassroots, are overlooked. Perhaps one could not speak of a broader user movement at the time, but the seeds had been sown, and many of the activities of people testify to what Diana Rose calls 'hidden activism.' As she puts it, "this [hidden] collectivity is made of 'small groups of unrepresentative people' who are either sicker (i.e., angrier) or more articulate than 'normal' patients" (Rose, 2018, p. 736).

In general, this period was important for the creation of knowledge, methods, and technologies, and thus for providing the basis for later reform of the system. But in terms of deinstitutionalisation, the development of a community provision actually did not reduce the numbers in institutions. It also took place almost exclusively in the social care sector, while psychiatry remained more or less as it was. The lesson of this period was that to actually make deinstitutionalisation happen, more is needed than establishing community services, like: the planned resettlements from institutions, the political will, the legislation, the funding, in short, the reform of the entire system (Flaker et al., 2008; Rafaelič et al., 2017).

\subsection{0s-2010s: Opening Up of Institutions and Changing the Role of the Residents}

The real deinstitutionalisation process in the public sector was initiated in the first decade of this century by the resettlement of the long-stay inmates of Hrastovec (almost 300 out of 650 residents in few years), followed also by another five long-stay institutions that also began to open their own group homes which resulted in 1,259 resettlements or more than a quarter of total capacity of long-stay institutions in Slovenia. These social care homes proved that the transformation of institutions was possible, that it was possible to change the way of work, and resettle even people with the most intensive needs. However, when deinstitutionalisation would have to become a principle guiding the whole system, the process came to a standstill. Among the reasons for these halts the managements of the institutions mentioned: a lack of political will, legislative restrictions, bureaucratic obstacles, the additional cost that residential units bring beside the cost of the maintenance of the institution, no sufficient funding, and others (Flaker et al., 2008, 2015, 2020; Rafaelič et al., 2017). Long-stay institutions also remained big employers of the local population, especially in rural areas. Many workers fear that deinstitutionalisation will cause unemployment, and that it is better to keep the existing welfare system in place (Zaviršek, 2017).

In terms of user involvement, good examples mainly include involvement practices at the operational level. For example, in Hrastovec, they employed some interesting innovative methods. The residents were invited (and were trained) to take the role of key-workers and advocates for other users who needed more support and encouragement. This experience showed that the users/key-workers became more confident and that other users accepted the support from their peers much better than the support from staff members (Strmšek, 2007). In line with the research question, we can certainly say that these processes at least gave more influence to the 'more able' residents, increased their autonomy, and presented the opportunity to enter into more equal relationships. However, these were not simple processes: on the contrary, they required a daily struggle with the remains of the institutionalised and patronising mentality from the staff and residents.

Studies have shown that an impact is only visible where participation truly becomes an integrated part of the philosophy of an organisation and the people who work there. If participation is seen only as an activity 'added-on' to services, rather than as a way of changing power relations, it can be removed as easily as it was provided (Hernandez et al., 2010, p. 717). This was the case with the innovation of 'users as keyworkers.' This innovation was increasingly becoming only an 'add-on' until it was abolished with the next management. 


\subsection{0-2020: Fourth Wave: Between Struggle for a Decent Life Outside Institution and Demands to Be Heard}

3.4.1. At the Turn of the New Decade: Formalisation of Users' Participation and Users' Research

After the process came to a standstill, civic movements again started to call attention to the necessity of re-establishing the process of the transformation of the institutional form of care. At this point, in 2010, a walkout-a $700 \mathrm{~km}$ march from institution to institution-was staged to raise awareness and promote deinstitutionalisation. Some residents of institutions who joined the march on the way stayed and started to live in the community with the support of activists (Flaker \& Rafaelič, 2012; Rafaelič \& Flaker, 2012). Such was Mijo Poslek, who spent 40 years in various asylums (we met him in the first camp in Hrastovec). Under the slogan "We are All Mijo Poslak," the movement addressed direct demands to the ministries to launch concrete actions towards community care provision (Agency IN et al., 2012).

The turn of the decade was marked by the newly defined role of the users as being more explicitly participatory. The user perspective became recognised as being of key relevance, at least at the declarative level, and the user representatives were gradually introduced, but mostly just in user councils in NGOs. In the academic sphere, this was reflected in a more systematic inclusion of users in education and research (Videmšek, 2013, 2021). The Mostovi (Bridges) user association undertook the first autonomous user research study of the critical areas of income and work. The findings of the study pointed to a high degree of disability retirement and unemployment after the onset of mental difficulties. In order to cover their basic living expenses, and also in order to remain active, the users are often forced to work illegally and to enter risky working relationships (Cigoj-Kuzma, 2010). When users do the research, that is, when they really can make decisions about which topics to explore and which issues to raise, their research is often about poverty and basic survival, because this is something that most deeply marks their lives and requires the fastest systemic solutions. The themes that they raise are deeply social and deeply political. Although the activities carried out by the Bridges user group included peer advocacy and self-help, implying participation on the personal and organisational levels, the main achievement of this period seems to be the concrete shift of participation to the strategic level (research, going public).

\subsubsection{The Gap between the Systemic Reforms and Grassroots Knowledge}

Recently, a trending topic is the new 'fourth wave' of the transition to the community forms of care, which comes as a guideline and requirement of the European Union. Among the positive shifts in this context, The Resolution on the National Programme for Social Care 2013-2020 (Republic of Slovenia, 2013) should be mentioned, which announces a substantial reduction of institutional capacities (from $50 \%$ to $80 \%$ for individual categories of residents), and a large increase in services in the community. Recently, the Governmental Office for Development and European Cohesion Policy issued a grant decision for two pilot deinstitutionalisation project units, the first in a social-care home and the second in a centre for training, work, and care for people with intellectual disabilities which received European Social Fund support to make a transition of care into the community over the next few years. A project unit for deinstitutionalisation was established at the Ministry of Labour, Family, Social Affairs and Equal Opportunities to draft sectoral strategies which will allow for delivering a coordinated action in this field. In all these big, promising, and groundbreaking developments the voice of the users has not been prevalent. Big decisions about the change of the system are being adopted on policy levels and in the closed circles of the sectorial ministries and experts. On the other side of the divide, the user research generates new 'grassroots knowledge,' which, however, also does not have adequate channels to reach the decision-makers.

On the positive side, we are dealing with a very important shift at the declarative level, when also at higher levels decision-makers increasingly recognise (or are urged by the EU) the importance of user participation-but a concrete step of implementation is still too rare. While the Resolution on the National Mental Health Programme 2018-2028 (Republic of Slovenia, 2018) foresees user participation on all decision-making levels, and even the user council was set up to participate in the making of the resolution, the 'voice of the users' seems to have been only declarative (in the last moment, instead of the user representative they appointed a representative of relatives to this position). The result is two parallel, separate realities still standing apart from each other. In real life, this gap can mean numerous complications.

A decade later, it is obvious that none of the real problems that were opened up by the first user research study was not systemically solved. Today, users are working on a new study conducted in the framework of Svizci. This new study re-opens old problems in the areas of work, housing, and survival (Cigoj-Kuzma et al., 2019). I conducted a 3-hour interview in a focus group with its three key members, at the Faculty of Social Work (24 April 2019). The most frequent metaphor that they used, when describing their experience with the social care and mental health system was that of a 'closed door': "Big changes led by the ministry may be alright, I don't know, but only experience matters. When you have the experience, the doors are closed for you." The transitions to independent life have remained the most burning issue. The problem are rents, as the rental of a place 
to live is higher than a person's disability pension. Social assistance benefits do not cover other expenses, and it is becoming ever more difficult to be eligible for them. To put it simply, independent life is difficult to afford, which is why many people are destined to live in institutions or group homes or are barely getting by in their parents' homes. The problem is that systemic regulations and legislation are not written from the users' experience ("The system puts up front some strange, ideal user that does not exist"). At present, we can repeat once again, in the words of Liz Sayce (2000, p. 83), "users enjoy only the illusion of citizenship." Their wish is to encourage people to join them in resolving their shared problems: "We depend too much on institutions, and we learn too little from our own practice." In the users' public tribune (2 March 2021, via Zoom), it became clear that during the Covid-19 pandemic, of all the actors in the field of mental health, it was the users who built the human solidarity network to the greatest extent.

\section{Between a Movement and a Seat on the Users' Council: A Discussion on 35 Years of Deinstitutionalisation and User Participation in Slovenia}

While returning to the main questions raised at the beginning of this article, we also try to summarise the main forms and characteristics of user participation and the lessons learned in different periods. Unfortunately, I could not mention all the user groups, initiatives, or forms of participation, for instance, the support group of voice-hearers (Dekleva \& Škraban, 2019) or one of the oldest user organisations for the self-help of people who had experienced depression and anxiety; or literary autobiographies that were eye-openers for me (Ažman, 2007; Lapuh Maležič, 2016).

The review of the periods reveals that historical development was not always linear and did not necessarily proceed from a bad state of affairs to a better one. Some levels of involvement were more forward in one period and less in another, but we have been able to identify all levels (Crepaz-Keay, 2014).

Looking back on the independent user alternatives of the second wave and from today's perspective, what surprises us is their autonomy, and their self-confidence in establishing independent services in areas-which even now are firmly anchored in psychiatry (such as user-led crisis centre). They aspired to work with other users and professionals to organise support for themselves, and to have control in helping relationships. They were aware of the importance of writing and finding their own language to reclaim an autonomy to describe their distress and what was helpful. They were important for the creation of knowledge and methods, and thus for providing the basis for later reform. The lesson from this period is that permanent funding and training are crucial for sustainability of innovations, so much the more for user-led projects.
In a different context, after the year 2000, the beginning of the reform of the social care homes highlighted the reflection about the ways of strengthening the influence of people who had lived for decades in the passive and mortifying roles of inmates in closed and secure units. Movement and user-led projects were in the background during this period. But the innovations that developed in this period were directly inspired by previously acquired experience and knowledge (international studies, user projects, camps, NGOs). Probably the most valuable message of this period is that it is importantwhen talking about user involvement in deinstitutionalisation processes-not to overlook the users who are the most seldom heard and least vocal about their needs. The first barrier to overcome is the staff belief that people with severe mental health problems are not able to contribute, when in fact they are if they are supported, encouraged, and trained (Hernandez et al., 2010).

The United Nations Convention on the Rights of Persons with Disabilities mainly brought the requirements for the necessity of formal user representative participation. This formal participatory mechanism is of key importance and big achievement, but it will not be able to become the tool of change if the awareness about rights and the need to take action will not involve a larger number of users. At the moment, there is still a large gap between the declarative participation policy and the lived participation experiences. Although we have primarily highlighted tokenistic practices, there are also good ones when users manage to use formal mechanisms to influence something more than just confirming the decisions of others. However, that gap is worth remembering while it exists. In the meantime-this is the good news - the autonomy and self-confidence of users' voices is visibly increasing. Nevertheless, genuine and routine channels for dialog must be established so that users' experiences and their proposals (i.e., from user research studies) find their way to decision-makers. In the movement, from its beginning in the mid of 1980s, users might participate more directly. Yet, the agenda is still mainly led by activists who, while solidarising with users, do not give up their position of the 'Others'; in other words, they are not ready to "transcend the traditional division of roles into allies on the one hand and those who need allies on the other" (Russo et al., 2018, p. 1).

However, it should also be noted that even as we write this article, some positive changes are taking place. Not only positive moves towards genuine deinstitutionalisation through a stronger political will than ever before, but there are also some signs of direct visible effects of the messages that have been sent out all these years. One of the two institutions that are now undergoing a transition, has set the empowerment of residents as one of the priority goals. They are trying to achieve it through regular assemblies of residents and staff on the wards, through the board of users, through residents' self-advocacy groups, and by working closely with the 
Svizci user group which provides training for residents to help them set up an advocacy group (and they are paid for this). At the same time, extensive trainings for staff who will eventually also 'resettle' from institutions is taking a place-an important theme which we barely touch in this article.

I see this as two achievements, firstly the mainstream institution has recognised the normally marginalised user knowledge as necessary to its work, and secondly, it has recognised user empowerment and participation as a necessary dimension of the processes of deinstitutionalisation. In relation to the research questions, users (at least some of them) here are involved in the deinstitutionalisation process (while the Svizci user group directly influences it), and they are gradually gaining more contractual power. A gap between the declarative participation policy and the lived experiences of participation here finally seems less wide here. The lesson learned here is that user empowerment and participation will not just spontaneously accompany organisational change; it must be foreseen in deinstitutionalisation policies, put in action plans, taken into account in funding, and monitored.

Although we criticise that the users' role within the systems of help is not relevant enough, their role can also get caught up in contradictions. The neoliberal framework of social policy presents a challenge for participatory practices. User participation, yes, sure, but in what? In the responsibilisation of impoverished users for their own well-being? The secure units packed with people do not lead the reflection towards the improvement of approaches to work in the community but look for funds to build new closed structures. Shall users participate in decisions legitimising such new buildings? Similar doubts can be raised at the fact that institutions opposing deinstitutionalisation are at the same time introducing progressive emancipatory methods, such as self-advocacy, peer support, or users' council in the units. In such circumstances, the user participation seems a perverse concept and paradoxically contributes to further strengthening the arguments for the existence of institutions. User participation is, in my view, inevitably linked to deinstitutionalisation, and vice versa. It is inevitable to understand participation not as a 'true' but rather as a 'contested' term, terrain of political debate (Ferguson, 2011, p. 57). By failing to recognise the conflicting agendas in debates about it, there is a risk to limit its liberatory potential.

\section{Conclusion}

Although deinstitutionalisation sometimes seems like a matter of reorganisation, it has always been linked with social movements. In today's strange times, in which on the one hand deinstitutionalisation has become a global platform, and on the other, the renewed demands for closing and coercion have entered areas where they did not exist before, applying to 'non-normative' groups at the new social margins, we need a broader coalition of deinstitutionalisation, alliances rather than allies (Russo et al., 2018, p. 1), to resist these trends. Perhaps we can start by reminding ourselves again that its real purpose is above all to open up society. But in doing so, the first step is-to conclude with Diana Rose (2018, p. 738): "To get rid of every last vestige of charitable but patronising approaches and be ready to face anger, suspicion, and dark, sometimes shocking, humour."

\section{Acknowledgments}

I would like to thank numerous people who have been my companions, co-workers, and fellow researchers on the path of deinstitutionalisation in Slovenia for the past 35 years. The article is part of the research activities funded by the National Research Agency of the Republic of Slovenia.

\section{Conflict of Interests}

The author declares no conflict of interests.

\section{References}

Agency IN, Occupy movement 15o, Direct Social Work, \& Walk-out movement. (2012, June 20). Odprto pismo MDDSZ: "Mi vsi smo Mijo Poslek" [Open letter to the Ministry of Labour, Family and Social Affairs: "We are all Mijo Poslek"]. Živa Demokracija. http://electronics85.njetwork.org/Odprto-pismoMDDSZ-Mi-vsi-smo-Mijo

Ažman, R. (2007). Depra (1st ed.). Društvo Mohorjeva družba in Celjska Mohorjeva družba.

Beresford, P. (2005). Social work and a social model of madness and distress: Developing a viable role for the future. Social Work \& Social Science Review, 12(2), 59-73.

Cigoj-Kuzma, N. (2010). Možnosti zaposlovanja ljudi S težavami v duševnem zdravju: Uporabniško raziskovanje [Employment opportunities for people with mental health problems: A user survey]. In V. Leskošek \& B. Petrović Jesenovec (Eds.), Od revščine in socialne izključenosti $k$ enakosti, socialni pravičnosti in solidarnosti: zbornik povzetkov [From poverty and social exclusion towards equality, social justice and solidarity: Book of abstracts] (p. 83). University of Ljubljana, Faculty of Social Work.

Cigoj-Kuzma, N., Tovornik, C., Kranjc, B., \& Videmšek, P. (2019). Zaposlovanje in bivanje ljudi s težavami z duševnim zdravjem [Employment and living of people with mental health difficulties]. In S. Bezjak (Ed.), Humanizem in etika $v$ socialnem delu: Zbornik povzetkov [Humanism and ethics in social work: Book of abstracts] (p. 39). University of Ljubljana, Faculty of Social Work.

Crepaz-Keay, D. (2014). Effective mental health service user involvement: Establishing a consensus on indi- 
cators of effective involvement in mental health services [Doctoral thesis, Middlesex University]. Middlesex University Research Repository. https://eprints. mdx.ac.uk/13932/1/DCrepaz-Keay_thesis.pdf

Dekleva, B., \& Škraban, J. (Eds.). (2019). Svet, ki se sliši: Razvoj in izvajanje podpornih skupin za slišanje glasov $v$ Ljubljani [World which is heard: Developing and introducing hearing voices support groups in Ljubljana] (1st ed.). University of Ljubljana, Faculty of Education.

European Expert Group on the Transition from Institutional to Community-Based Care. (2012). Common European guidelines on the transition from institutional to community-based care.

Ferguson, I. (2011). Personalisation, social justice and social work: A reply to Simon Duffy. Journal of Social Work Practice: Psychotherapeutic Approaches in Health, Welfare and the Community, 26(1), 55-73.

Flaker, V. (2015). Deinstitutionalisation as a machine. Dialogue in Praxis, 4(17), 1-23.

Flaker, V., Jović, V., Cvetković Jović, N., \& Rafaelič, A. (2020). Borderline deinstitutionalisation: Yugoslav resonance and dissonance with Basaglia. In T. Burns \& J. Foot (Eds.), Basaglia's international legacy: From asylum to community (pp. 295-316). Oxford University Press.

Flaker, V., \& Leskošek, V. (1995). The impact of a tempus community mental health training programme on Slovenian mental health social work. In S. Ramon (Ed.), International perspectives of health social work in the 1990s (pp. 19-29). ATSWE.

Flaker, V., Mali, J., \& Urek, M. (2008). Deinstitutionalisation process in long-term mental health institutions in Slovenia. In M. London (Ed.), Conference monograph, Vilnius Lithuania 2007. European Network for Training Evaluation and Research in Mental Health.

Flaker, V., \& Rafaelič, A. (2012). The walkout. Dialogue in Praxis, 1(14), 119-131.

Flaker, V., \& Ramon, S. (2016). From institutional to community care: Social work of opening spaces and new solidarities (social work and deinstitutionalisation). Dialogue in Praxis: A Social Work International Journal, 5(18), 42-48.

Flaker, V., \& Urek, M. (Eds.). (1988). Hrastovški anali za leto 1987 [Annals of Hrastovec for year 1987] (1st ed.). RK ZSMS.

Flaker, V., Cigoj-Kuzma, N., Grebenc, V., Kodele, T., Kranjc, B., Pirnat, T., Smole, A., Urek, M., Videmšek, P., \& Žnidarec Demšar, S. (2007). Empowerment in theory and practice (1st ed.). University of Ljubljana, Faculty of Social Work.

Flaker, V., Rafaelič, A., Bezjak, S., Ficko, K., Grebenc, V., Mali, J., Ošlaj, A., Ramovš, J., Ratajc, S., Suhadolnik, I., Urek, M., \& Žitek, N. (2015). Priprava izhodišč deinstitucionalizacije $v$ Republiki Sloveniji [Preparation of starting points for deinstitutionalisation in the Republic of Slovenia]. University of Ljubljana, Faculty of Social Work.
Hernandez, L., Robson, P., \& Sampson, A. (2010). Towards integrated participation: Involving seldom heard users of social care services. British Journal of Social Work, 40(3), 714-736.

Lamovec, T. (1995). Ko rešitev postane problem in zdravilo postane strup: Nove oblike skrbi za osebe $v$ duševni krizi [When the solution becomes a problem, and the cure becomes a poison] (1st ed.). Lumi.

Lamovec, T. (1998). Psihosocialna pomoč v duševni stiski [Psychosocial help in mental distress] (1st ed.). University of Ljubljana, Faculty of Social Work.

Lamovec, T. (2001). Uporabniška iniciativa in država [Users' initiatives and the state]. Social no delo, 40(1), 29-36.

Lapuh Maležič, J. (2016). Težkomentalci [Heavy mental] (1st ed.). Lud Literatura.

Markun, G., \& Švara, R. (Directors). (2018). DocumenTRATE or moments of beauty in troubled times [Motion picture]. Koprodukcija Plus.

Mezzina, R., Rosen, A., Amering, M., \& Javed, A. (2019). The practice of freedom: Human rights and the global mental health agenda. In A. Javed \& K. N. Fountoulakis (Eds.), Advances in psychiatry (pp. 483-515). Springer.

Muratović, A. (Director). (2020). Muzej norosti [Museum of madness; Motion picture]. RTV Slovenija.

Omeni, E., Barnes, M., MacDonald, D., Crawford, M., \& Rose, D. (2014). Service user involvement: A survey of service user and staff perspectives. BMC Health Services Research, 14(1). https://doi.org/10.1186/ s12913-014-0491-7

Penney, D., \& Prescott, L. (2016). The co-optation of survivor knowledge: The danger of substituted values and voice. In J. Russo, \& A. Sweeney (Eds.). Searching for a rose garden: Challenging psychiatry, fostering mad studies (p. 35-45). PCCS Books.

Rafaelič, A., Ficko, K., \& Flaker, V. (2017). Prehod k skupnostnim oblikam oskrbe $v$ Sloveniji [The transition to community-based care in Slovenia]. Socialna pedagogika, 21(3/4), 183-210.

Rafaelič, A., \& Flaker, V. (Eds.). (2012). Iz-hod iz totalnih ustanov med ljudi [Walking out of institutions (to be) with people; Special issue]. Časopis za kritiko znanosti, domišljijo in novo antropologijo, 250. https://www.ckz.si/arhiv/ckz250.pdf

Ramon, S., Brooks, H., Rae, S., \& O'Sullivan, M. J. (2017). Key issues in the process of implementing shared decision making (DM) in mental health practice. Mental Health Review Journal, 22(3), 257-274.

Ramon, S. (1985). Psychiatry in Britain: Meaning and policy. Croom Helm.

Ramon, S. (1995). Slovenian social work: A case study of unexpected development in the post-1990 period. British Journal of Social Work, 25, 513-528.

Republic of Slovenia. (2013). Resolucija o nacionalnem programu socialnega varstva za obdobje 2013-2020 [Resolution on the national programme for social care 2013-2020]. Official Gazette of the Republic of 
Slovenia, No. 39/2013.

Republic of Slovenia. (2018). Resolucija o nacionalnem programu duševnega zdravja 2018-2028 [Resolution on the national mental health programme 2018-2028]. Official Gazette of the Republic of Slovenia, No. 24/2018.

Robar Dorin, F. (Director). (1988). Ljudnica [Madpeople's house; Motion picture]. Filmske in gledališke alternative Novo mesto and Dokumentarni program TV Ljubljana.

Rose, D. (2018). A hidden activism and its changing contemporary forms: Mental health service users/survivors mobilising. Journal of Social and Political Psychology, 6(2), 728-744.

Russo, J., Beresford, P., \& O'Hagan, M. (2018). Commentary on: Happell, B. \& Scholz, B. (2018). Doing what we can, but knowing our place: Being an ally to promote consumer leadership in mental health. International Journal of Mental Health Nursing, 27, 440-447.

Ryan, P., Esther, A., \& Griffiths, C. (2012). Empowerment: Key concepts and evidence base. In P. Ryan, S. Ramon, \& T. Greacen (Eds.), Empowerment, lifelong learning and recovery in mental health (pp. 135-145). Palgrave Macmillan.

Sayce, L. (2000). From psychiatric patient to citizen (1st ed.). Macmillan.

Spry, T. (2001). Performing autoethnography: An embodied methodological praxis. Qualitative Inquiry, 7(6), 706-732.

Strmšek, K. (2007). Stanovalci v vlogi ključnega delavca $\checkmark$ Zavodu Hrastovec [Residents in the role of keyworker in social-care home Hrastovec]. University of Ljubljana.

Sweeney, A., Fahmy, S., Nolan, F., Morant, N., Fox, Z., Lloyd-Evans, B., Osborn, D., Burgess, E., Gilburt, H., McCabe, R., Slade, M., \& Johnson, S. (2014). The relationship between therapeutic alliance and service user satisfaction in mental health inpatient wards and crisis house alternatives: A cross-sectional study. PLOS ONE, 9(7). https://doi.org/10.1371/ journal.pone.0100153

Tew, J. (2011). Social approaches to mental distress (1st ed.). Palgrave Macmillan.

Turnpenny, A., Petri, G., Finn, A., Beadle-Brown, J., \& Nyman, M. (2018). Mapping and understanding exclusion: Institutional, coercive and communitybased services and practices across Europe (Project Report). Mental Health Europe.

United Nations. (2006). Convention on the rights of persons with disabilities.

Urek, M. (2017). Unheard voices: Researching participation in social work. European Journal of Social Work: The Forum for the Social Professions, 20(6), 823-833.

Urek, M., \& Zaviršek, M. (Eds.). (1991). Subpsihiatrične študije: Hrastovški anali za leto 1989 [Sub-psychiatric Studies: Annals of Hrastovec for year 1989; Special issue]. Časopis za kritiko znanost, 19(138/139).

Videmšek, P. (2013). Iz institucij v skupnost: Stanovanjske skupine nevladnih organizacij na področju duševnega zdravja [From institution to community: Group homes run by mental health NGOs] (1st ed.). University of Ljubljana, Faculty of Social Work.

Videmšek, P. (2021). Blank page: Involvement of expert by experience in social work education in Slovenia. In $\mathrm{H}$. McLaughlin (Ed.). The Routledge handbook of service user involvement in human services research and education (pp. 174-185). Routledge.

World Health Organisation. (2005). Mental health atlas 2005.

World Health Organisation. (2010). User empowerment in mental health: A statement by the WHO regional office for Europe.

World Health Organisation. (2015). The European mental health action plan 2013-2020.

Zaviršek, D. (2017). Delayed deinstitutionalisation in post-socialism. European Journal of Social Work: The Forum for the Social Professions, 20(6), 834-845.

\section{About the Author}

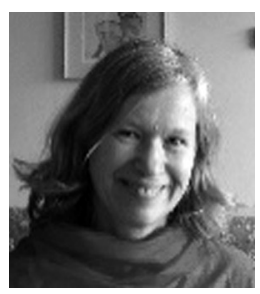

Mojca Urek is an Associate Professor of Social Work at the University of Ljubljana, Faculty of Social Work, since 1992. She has undertaken research on the narrative approaches in social work, mental health, deinstitutionalisation, gender-based violence and LGBT+ inclusive social care. She was the national lead in five European projects. She is the author of the monograph Stories at Work: Narrating, Recording, and Reporting in Social Work and is the co-author of five other monographs. 